\title{
Widening the Perspective on Industrial Innovation: A Service-Dominant-Logic Approach
}

Heidi M. E. Korhonen

\author{
" Any existing structures and all the conditions of doing") \\ business are always in a process of change.
}

Joseph Schumpeter (1883-1950)

Economist and political scientist

\begin{abstract}
The servitization of industry has progressed from services as add-ons to services as solutions. Today, industrial innovation needs an even broader perspective that moves towards service-dominant logic. This logic emphasizes value co-creation in actor-to-actor networks and requires new organizational structures and practices in industry. The article presents the case of a Nordic manufacturer of arc welding equipment that has gone through an extensive development program to become more customer and service oriented. An innovative offering created during the program is analyzed as an example in order to gain deeper insight about the concrete application of service-dominant logic in business. In addition to the outcome perspective, the article discusses the implications of the service-dominant logic for innovation practices. The article illustrates the behaviour of cutting-edge servitizing manufacturers and argues that similar behaviour can be expected to become a necessity in all industrial companies with large structural changes.
\end{abstract}

\section{Introduction}

There is a constant need for manufacturing to renew itself due to competition. Today, renewals are driven in particular by intangible assets such as human capital, intellectual capacity, and service provision. Since the end of the 1980s, manufacturing companies have added services to their offerings in order to create closer and more long-lasting relationships with their clients. However, it has been common to implement this practice - called "servitization" (Vandermerwe \& Rada, 1988; Neely, 2008; Baines et al., 2009) - in a way that has not changed the basic view of the primary role of the provider in the emergence of value. Value has still been seen as something created in production and then delivered to clients (Michel et al., 2008). It was not until Vargo and Lusch $(2004,2008)$ presented their argument about the necessity of a new service-dominant logic that the central position of customers in value creation began to gain ground. According to service-dominant logic, this position is based on the fact that value is revealed only when goods and services are used and when an individual good or service acquired from a single provider is linked to other goods and services acquired from other providers. The last mentioned process of resource integration is an indispensable part of value creation and is carried out by the user as well as the provider. Consequently, value is always co-created: the provider has to make its best effort to facilitate the emergence of value via purposeful goods and services, but the realization of value takes place in the use context.

Service-dominant logic links the value logic to the production of both goods and services. It considers the reciprocal nature of value creation a more crucial phenomenon than the production outputs in the form of individual goods and services. According to Vargo and Lusch (2004), goods and services are important, but value is not their inherent property; they are first and foremost conveyors of competences for the benefit of another party. Other authors, analyzing the implications of service-dominant logic from managerial viewpoints, have pointed out that this view should not lead to diminishing the importance of goods and services - 


\title{
Widening the Perspective on Industrial Innovation: A Service-Dominant-Logic Approach
}

\author{
Heidi M. E. Korhonen
}

they do not go away. Rather, they must be designed around co-creation of human experiences through multi-sided interactions (Ramaswamy, 2009, 2011). In the service context, the formulation of value propositions is of particular importance because they are the entities based on which customers make purchasing decisions (Maglio \& Spohrer, 2013). Finding a way to link the views of service-dominant logic with the concrete production outputs is essential for the current development in the servitization of manufacturing.

Although most innovation research has focused on product and process innovations, present discussion calls for a broader notion of innovation (Tidd et al., 2001). This discussion returns back to the definition of innovation by Schumpeter (1934), who laid the ground for studying innovation as a socioeconomic evolutionary process resulting in new combinations of resources. His categorization of innovations is wide and enables the analysis of renewals at different levels: products and methods of production; sources of supply and exploitation of new markets; and methods of organizing business. The service-dominant-logic view on innovation based on value co-creation practices - has much in common with the Schumpeterian views. In addition to products and services, which manifest value co-creation practices, service-dominant logic advises firms to focus on the overall value-proposition design. This approach can be seen as a systematic search for business model innovation from the provider's perspective (Maglio \& Spohrer, 2013).

This article studies: i) how the view of value as co-created can be applied to widen the perspective on industrial innovation and ii) what are the implications of this widening for the development of innovation practice. The study has been carried out as a single-case study of a Nordic welding equipment manufacturer that has gone through an extensive development program to increase its innovative capability in a more customerand service-oriented direction. The program has led to the development of several offerings that represent a novel type of industrial service business.

To understand the current development in industrial innovation in detail, we will analyze the development of one specific offering in our case company. We will use this example to illustrate the relationships between industrial service innovations as add-ons, solutionsbased innovations, and innovations based on servicedominant logic. We will then discuss innovation practices for systematically and efficiently producing innovations consonant with the view of value as co-created.
This article is structured as follows. We first explain the background and theory to better understand innovation as a co-development process and as novel outcomes and practices. We then describe our methodology and case selection. After this, we analyze the new innovative solution and discuss the innovation practices used in its creation. We finish our article by discussing the managerial implications of widening the perspective on industrial innovations.

\section{Innovation in the Light of Service-Dominant Logic}

In the history of manufacturing, innovation was seen primarily as a matter of technological development, and services were regarded as an unavoidable expense. The current synthesis approach suggests that service innovation brings neglected aspects of innovation to the fore (Coombs \& Miles, 2000). Service-dominant logic is consistent with the synthesis approach, but it brings novel understanding to the discussion. It can be understood either as an innovation theory or as an approach for leveraging other discussions on innovation. In this article, we take the former viewpoint and point out its implications for the practice of innovation management.

Industrial companies often start servitization by developing services to support products (Oliva \& Kallenberg, 2003). However, when their service business matures, they no more consider services as mere add-ons to products, but innovate services supporting customers (Mathieu, 2001). Customer centricity has often led to providing solutions, in other words, individualized and interactively designed offers for complex customer problems (c.f. Evanschitzky et al., 2011). In solutions, products and services are integrated and the relationship between the buyer and the seller is close. Instead of the traditional approach of managing services as a separate function, manufacturers may turn their entire business to service logic (Grönroos \& Helle, 2010). The involvement of customers may take place both in the innovation process and in the joint creation of value.

Despite the change, servitization alone does not seem to represent a panacea for manufacturers (Baines et al., 2009). The service-dominant-logic approach includes the ideas of the synthesis perspective and solution business, but it widens the scope of the discussion. In particular, service-dominant logic broadens the view from a provider-customer dyad to a broader system of actors (Vargo \& Lusch, 2011) - an approach that has been rare in service innovation research (Carlborg et al., 2013). 


\section{Widening the Perspective on Industrial Innovation: A Service-Dominant-Logic Approach}

\section{Heidi M. E. Korhonen}

Also, in addition to operand resources that require action taken upon them to be valuable, service-dominant logic stresses the primacy of knowledge and technology because they are capable of acting on other resources to contribute to value creation (Vargo \& Lusch, 2004). Further, service-dominant logic emphasizes the role of institutions - social rules and norms that both constrain and enable behavior - as resources that are needed for actors to co-create value. Markets can be seen as institutionalized solutions of resource application to human problems or needs. The way in which novelties become stabilized (i.e., institutionalized) in the markets is one of the most interesting issues in innovation according to service-dominant logic. Here, the view is very similar to the current emphasis of general innovation research on the diffusion (not only invention) of innovations.

These new insights are in line with innovation studies that highlight innovation as processes and practices (Gallouj, 2002; Lundvall, 2007). Innovation can be seen as a path dependent co-development process, and its outcomes include the adoption of new practices. We now use the service-dominant-logic theory in order to better understand the wide perspective on innovation from these points of view.

\section{Innovation as a co-development process}

Service-dominant logic emphasizes social institutions and therefore encourages the study of practices - "embodied, materially mediated arrays of human activity centrally organized around shared practical understanding" (Schatzki, 2005). Value co-creation takes place through the enactment of practices in systems at micro, meso, and macro levels (Akaka et al., 2013). These practices and systems cannot be created from nothing, but are recreated by integrating existing resources in novel ways. As Arthur (2009) puts it, novel technologies arise from existing technologies. In order to better understand the wide concept of innovation, technology should be understood in a broad way, as an operant resource and "as a set of practices and processes, as well as symbols, that contribute to value creation or fulfill a human need" (Akaka \& Vargo, 2013). The most enduring and prevalent practices can be referred to as institutions (Giddens, 1984).

Value propositions are made about new practices for value co-creation, but it is in the use phase when the practices are enacted and come to being. Therefore, the resource integration for innovation occurs through both value proposition and value determination phases
(Akaka \& Vargo, 2013). There are parallels between value proposition and determination in service-dominant-logic theory and invention and innovation adoption in general innovation-diffusion theory (c.f. Rogers, 2003). Service-dominant logic strives to incorporate the issues of contextual value and multiple actors to the phenomenon. In most cases of industrial innovation, both the value proposition and determination involve multiple stakeholders instead of just one and are affected by the institutional landscape.

As has been described above, innovation is not a onedirectional development activity by any single actor. Instead, it is co-development between the different actors of the service system. Innovation is a path-dependent and recursive process. It can be understood as mutual learning between actors and as the emergence of corresponding value co-creation systems, again implying that social capital matters - it has an important impact on a company' innovative capability.

In service-dominant logic, one of the most important operant resources is entrepreneurial spirit (Vargo \& Lusch, 2006) - the mental capabilities for resource integration characteristic of entrepreneurs. Based on this, and in line with Schumpeter (1934), we accentuate that anyone can act entrepreneurially and stress its meaning for innovation. Innovative activity can be characterized as an actor's entrepreneurial search for new beneficial configurations for resource integration that emphasizes operant resources. Entrepreneurs search for change, respond to it, and exploit it as an opportunity (Drucker, 1964). This process of search and experimentation always involves uncertainty. Therefore, instead of trying to predict uncertain markets, experienced entrepreneurs co-develop novel markets with committed stakeholders (Read et al., 2009).

All humans participate in value co-creation through the repeated reproduction of institutionalized practices in their daily activities whether or not they do it entrepreneurially. The activity of co-development differs from this activity of co-creation. Co-development is proactive search for new actors, resources and configurations, making new kinds of value propositions and reciprocally assessing other actors' novel value propositions. It is a purposive activity aimed at transforming the structure of value co-creation in interaction with others. Actors can appreciate co-development either instrumentally through the appreciation of its aims or intrinsically through the appreciation of participating in the social interaction per se. 


\title{
Widening the Perspective on Industrial Innovation: A Service-Dominant-Logic Approach
}

\author{
Heidi M. E. Korhonen
}

\section{Innovations as novel outcomes}

Scholars that study service-dominant logic are cautious when it comes to discussing innovation outcomes because such an approach easily leads to goods-dominant logic. Yet, goods and services, and activities and processes, still remain (Ramaswamy, 2011). Also, it is the resulting impact that determines whether innovation makes us better off or not. Therefore innovation as resulting novel practices and their concrete manifestations as, for example, products and services should not be ignored.

Edvardsson and Tronvoll (2013) see the results of innovation as new practices. They emphasize structuration (Giddens, 1984) and view innovation in service-dominant logic as changes in social structure that allows actors to co-create value. These changes stem from new configurations of resources or new knowledge of shared rules and norms. We agree with this view and characterize innovative outcomes as new value co-creation practices embedded in social structure. The new practices can either enable customers to attain something or relieve customers from something (Michel et al., 2008). They can address different benefits and even different level benefits than the old practices. The benefits may vary for different stakeholders. New levels of value are addressed, for example, when focus is shifted from efficiency to effectiveness or when the experiential and meaning-laden nature of value is emphasized. Service-dominant logic also stresses that operant resources such as skills and knowledge can be embedded in the offering with the purpose of making customers smarter.

The novel practices are often crystallized in concrete entities such as products, services, or technologies. Humans make observations through their physical senses, and they depend on their bodies as a means to act and participate in any social interaction. They have a limited view of the actions of others and of the consequences of their own actions and the actions of the actor-to-actor network as a whole. Products, services, and technologies are resources that aid humans by extending their senses and capability to act. They always have some physical manifestation that works as a medium enabling the human-to-human interaction for value co-creation. However, only an experience can be appreciated as an end itself (Holbrook, 1999). Therefore, value is not an inherent property of products, services, or technologies. Instead, they are manifestations and enablers of practices: configurations of resource integration that can be further integrated for enhancing value co-creation in social interaction.
All the forms of innovation originally proposed by Schumpeter (1934) can be considered to be novel value co-creation practices. Therefore, service-dominant logic as an innovation theory is wide enough to include all innovations, including new markets and reorganization of industries as well as new products and services.

\section{Methodology and Case Company}

Service-dominant logic is young as an innovation theory, and there is a clear need for more practically relevant knowledge about its implications for innovation management. In particular, we want to illustrate how it widens the perspective on industrial innovation and what effect this widening has for the innovation practice in industry. A case study is a suitable methodology for us because it fits especially well with answering "how" or "why" types of questions (Yin, 1994).

We first use our empirical case study to illustrate and concretize how to further widen the abstract idea of an innovation. We analyze the sample offering using service-dominant-logic theory to clarify the resulting innovations as novel value co-creation practices. Then, we further discuss the innovation practices used in creating this type of innovation.

Our case company is a Nordic manufacturer of arc welding equipment and a provider of solutions for highly productive welding. It has gone through an extensive development program to increase its innovative capability and to turn from an equipment company to a more customer- and service-oriented direction. It is an entrepreneurial and innovative company serving the high-end market. It has own offices in 15 countries and a strong dealer network with export to 80 countries. It has about 650 employees and its global revenue totals 120 million euros a year.

The company has developed services previously. We assess the company's earlier level of servitization as mainly a supplier of machines and add-on services, with some solutions for specific uses or user groups. During the development program, the company took clear steps to a more mature solutions-provider phase. These steps include development of customer centricity, incorporation of customers' voice, and the development of a wide range of new integrated product and service offerings focused on supporting customers' value creation processes. Service logic now better encompasses the entire company and proper attention has also been given to customer relationship management. In addition to these qualities of a solutions pro- 


\section{Widening the Perspective on Industrial Innovation: A Service-Dominant-Logic Approach}

\section{Heidi M. E. Korhonen}

vider, the company has been able to develop certain level of preparedness and capabilities necessary for a company that wants to apply service-dominant logic in its innovation efforts.

\section{Data collection}

Our empirical data was collected from the company's extensive development program taking place during 2011-2013. The author, together with a larger research group, has been involved in the program since its beginning. Case data has been collected from various sources, including meeting notes, slide presentations, memos, process descriptions, conceptual descriptions, web pages, and observations. Every half a year, the author together with colleagues has written a thorough report about the progress of the development program, utilizing detailed material. These reports have also been used as data for study. In addition to the data collected as part of the development program, three company representatives in high management positions and two customer representatives were interviewed. The author has had a dual role in the process. The research group - including scholars in innovation management, service-dominant-logic and strategic renewal - has brought its expertise to the development program together with several other expert groups, and affected the change in the company's business and innovation practices.

\section{Case Findings}

In our theoretical discussion, we ended up with a view of innovations as novel value co-creation practices embedded in social structure. They come into being as customers and other relevant actors accept value propositions and enact them. In order to better understand industrial service innovations from this perspective, we now analyze a new offering created by the case company and then discuss our empirical findings on innovation management.

\section{Analysis of a systemic industrial service offering}

We find the offering an enabler of new value co-creation practices and summarize the main points of this analysis in Figure 1. The offering is a system for managing quality and productivity of welding work. It links together different modules or sub-offerings that fit together and can be used either together or separately. The modules are complementary, having the potential to become more valuable as more modules and actors are integrated together. The offering includes physical products such as welding machines and barcode readers, and services such as consultation and training, but it is best understood as a systemic, multi-actor valueproposition design capable of assisting customers in their value creation by making them "smarter" through the smart knowledge and connections it contains.

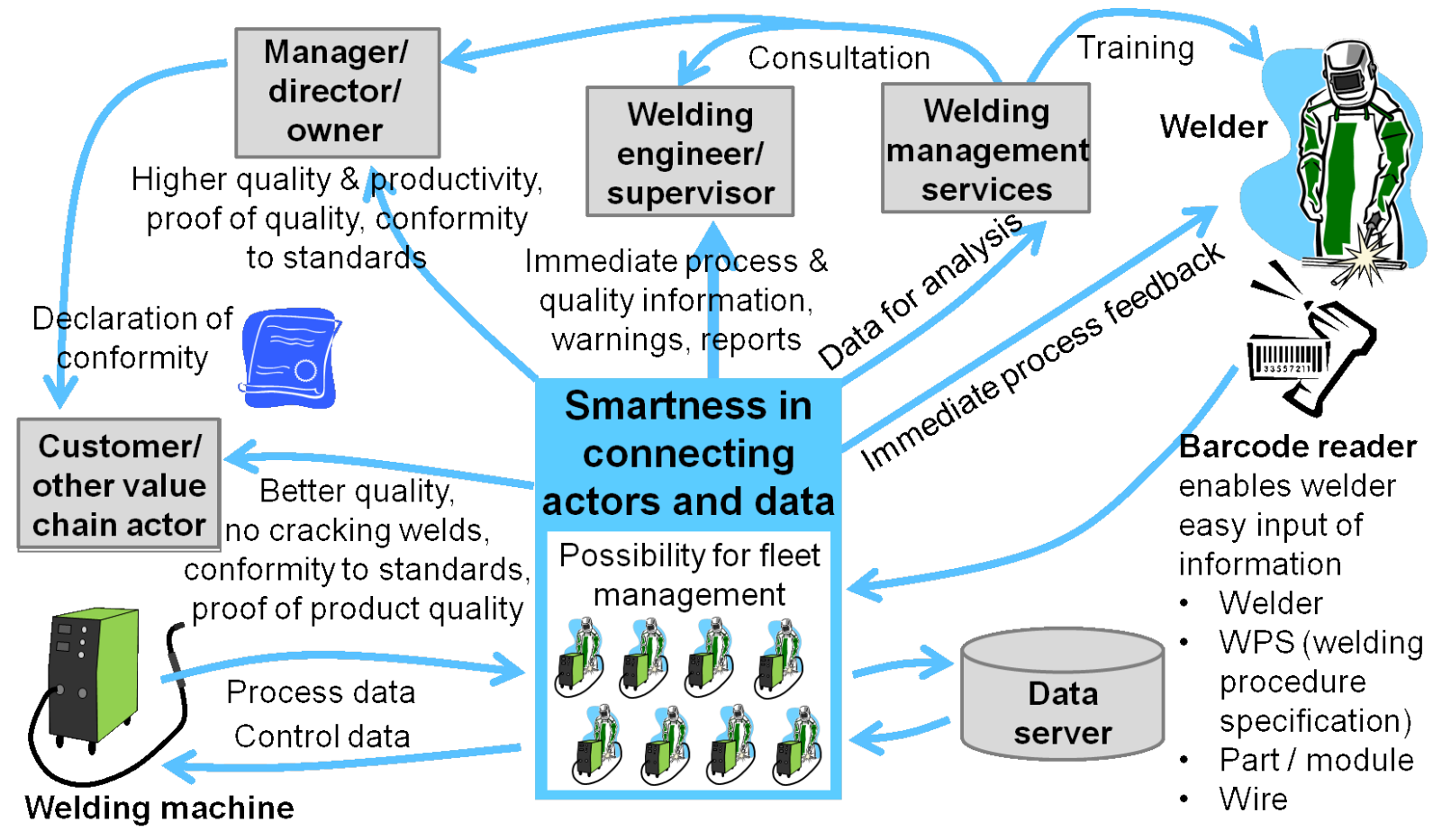

Figure 1. A systemic offering as an enabler of new value co-creation practices 


\section{Widening the Perspective on Industrial Innovation: A Service-Dominant-Logic Approach}

\section{Heidi M. E. Korhonen}

We now discuss this value proposition by starting from the lower left corner of Figure 1 and moving counterclockwise. We then further discuss institutions and other aspects of the offering not visible in the figure.

Welding machines are a basic product offering of the case company. They are physical manifestations of resource integration practices carried out by the case company. Customers integrate welding machines as resources in their own welding processes. However, value creation in welding work relies heavily on welders' competence and their compliance with welding procedure specifications. Welded joints are often safety critical, yet their metallurgic microstructures cannot be properly studied with non-destructive testing methods.

As a major benefit compared to welding machines alone, the systemic offering can be used to collect all welding data and to monitor compliance with welding procedure specifications for quality control. Because process data is collected and stored in a data server, it can be integrated with other information for quality and productivity improvements. An essential enabler of novel practices is $a$ barcode reader. It allows the welder to easily input important quality parameters into the system. Due to the barcode technology, it is easy for the welder to adopt the new quality-control practices. The system also gives the welder immediate process feedback about their own work.

The data can also be used as a resource for the case company's welding management services production, such as training and consultation. The data and the different reports and services are also an important resource for the welding supervisor as the system facilitates and automates production management. At the company level, the owner benefits through better quality and improved productivity, which lead to reduced costs and higher throughput. For the company, it is also very important that welding quality and conformation to welding procedure specifications can be verified. Quality problems of safety-critical welded parts can cause substantial liabilities. Customers of the welding shop can further utilize the declaration of conformity while doing business with final customers. Welded parts and their quality can be tracked throughout the production chain. Naturally, customers also benefit directly through better quality and the resulting safety for people and their value creation processes.

The offering allows for new practices of fleet management on the shop floor, and even globally. It connects together different data resources and actor resources, which enables smart value co-creation practices in a networked business environment. Therefore, it is a systemic value proposition design.

The system draws on many institutionalized practices of welding industry as resources, including arc welding technology and the use of welding procedure specifications. It also utilizes the institutionalized practices of information technology such as barcodes. The servitization of industry is also an important norm and a resource for welding management services.

An especially important institutional change in the welding industry is the rapid spread of quality management practices as an industry norm. Welded seams are safety critical and there is a global trend of emphasis on safety issues. Accidents such as the Gulf of Mexico oil spill have had a major effect on the required safety precautions in many industries and especially in the offshore industry. Europe is adopting new quality standards for welding. CE marking will be required for all steel and aluminum structures sold within the European Economic Area. The offering facilitates conformity to the new standards. The institutional norm for quality management is further intensified by urbanization and the rapid growth of the Chinese market. Due to the high demand, there is a global shortage of well-trained welders. The quality management tools help welding companies to cope with the high demand when there is a shortage of personnel.

Institutional inertia often makes it difficult to induce changes in practices of systemic value co-creation. However, institutions not only constrain behaviour they also enable it. The offering under study has been designed to meet the demand created by a major change in the institutional landscape of the welding industry. It does not try to fight major institutions, instead it utilizes them. For example, one of the first customers adopted this innovation in order to take proactive development steps, improve operations, and be well prepared for CE marking. Also, many of its large customers required operation almost at the level of the CE marking.

The offering can be viewed as designed around human value co-creation. Products, services, and technologies are an indispensable part of the design as enablers of human-to-human interaction. In this case, the main enabler of higher value creation is information technology that makes actions of the welder as well as functioning of the welding machine visible for other stakeholders across time and space. The offering embeds smart technology that helps each stakeholder utilize this knowledge and act smarter in his role. 


\title{
Widening the Perspective on Industrial Innovation: A Service-Dominant-Logic Approach
}

\author{
Heidi M. E. Korhonen
}

As an important difference to the typically dyadic value propositions of solutions business, the novel offering represents a multi-stakeholder value proposition for welders, welding engineers, managers, customers of the welding shop, and the provider of welding management services. The offering supports the interactive value co-creation between the different stakeholders at least as much as it directly supports the value creation of each individual stakeholder.

As the stakeholders accept the value proposition and adopt the new value co-creation practices, an innovation emerges. The innovation is not the offering per se, but the enactment of new practices by the different stakeholders. The offering is an enabler. The new products and services are critical enabling components that need to be created before the innovation as novel practices can take place. However, products, services and technologies as such are not sufficient development targets. Development efforts need to be aimed at systemic value co-creation.

The example represents a gradual shift towards servicedominant logic. The offering differs from typical solutions offerings and resembles a service-dominant-logic offering due to its value proposition that supports joint value co-creation of multiple stakeholders and due to the way it utilizes the systemic market dynamics created by the wider institutional change. It also leverages knowledge and technology the way that is stressed by service-dominant logic.

The analysis of the offering illustrated how the adoption of service-dominant logic widens the perspective on innovation. We will now discuss the innovation practice used in its creation. Our elaboration on it is brief because, as a dynamic capability, it is a sensitive issue.

\section{Understanding context and searching for win-win-win}

A view of systemic complementarity between multiple actors instead of a provider-customer view becomes obvious in the offering example presented above. The search for such win-win-win is a complex and uncertain task for which theory suggests an entrepreneurial approach. For this search, the company has developed shared organizational capability for understanding customers and proactively utilizing this understanding for new offering development, as the following quotation from a senior manager at the start of the program tells us:

"It is not enough to know customers' present needs... Customer satisfaction surveys tell us about past and present... we need to go further in thinking and develop a proactive approach."

A consultative sales model is an important entrepreneurial element of the innovation process that was developed. Sales people learn about customers' different contexts and proactively widen the discussion on possible sources of value in their search for mutually beneficial solutions with customers. They need to have a certain level of consulting capability in order to sell the smart offerings and consulting services. It is not easy for all seasoned sales people to learn the new approach. However, sharing success stories helps sales people learn from each other's experiences and widen their minds to new creative value propositions. Special attention has been given to ensuring that all sales people have proper skills in consultative sales and on developing tools for learning the new skills.

When developing multiple-actor value systems, insight needs to be gained about stakeholders in multiple roles and how they experience value creation and value destruction. In our case these multiple roles include welder, welding engineer, owner, service provider, dealer, and the customer of the welding company. All these actors each have their individual context that has an influence on their service experience. A very important part of this context is the everyday practices of these actors. For example, the case company uses an ethnographic approach that is suitable for studying the everyday practices, contexts, and experiences of the different actors. Also, other methods such as questionnaires are used and integrated into the critical process points of the research, development, and innovation process. The front office is used for searching weak signals. The case company has also organized its innovation process so that it can create a very extensive and deep understanding of its customers on multiple levels, for example, an understanding of customer's people, customer's business, the tools used, and the context.

\section{Co-developing value co-creation systems}

Firms depend on their relationships with their external environment for innovation. This dependency emphasizes the importance of social capital and long-term relationships with other innovative agents. The case company has built extensive external networks and long-term relationships to support its innovation activity. It has carefully chosen strategic research partners to collaborate with and to tap into important information sources. As an example, the development program involved a multitude of research organizations and companies to provide rich expert knowledge. 


\title{
Widening the Perspective on Industrial Innovation: A Service-Dominant-Logic Approach
}

\author{
Heidi M. E. Korhonen
}

The offering enables a change in the value co-creation system. From the provider's view, it can also be seen as a business model innovation. The idea is expressed in the following quotation from a senior manager discussing markets in different cultures:

"It is not the machines and their use, instead it comes more from business models and the whole system - how you offer support and how you do pricing. The machines are not that radically different and it accentuates contextual circumstances - the whole business model and how you approach through different channels how the business runs."

Technology, products, and services are not developed for their own sake; instead, they are developed to fill critical gaps so that value propositions can be made that fit the social context. In order to do this, the development program joined together technology development, business development, customer research, and organizational development. This approach proved to be a very successful research and development concept.

\section{Conclusion}

The servitization of industry has advanced from services as add-ons to services as solutions. The next logical step for industry is to widen its perspective on innovation based on the view of value as being co-created. It is a systemic and human-centered view that sees innovations as new practices in social interaction. First, this approach will be adopted by the advanced companies that want to be in the forefront of development. In the future, however, industry will face large structural changes, partly due to the positive forces of the knowledge society and new technologies such as the Internet of Things, robotics, and additive manufacturing - and partly due to more negative forces such as the coming shortage of resources and the need for a more sustainable economy. In the phase of large structural changes, a wider innovation concept that includes new market structures and the reorganization of industries is a necessity. Service-dominant logic can provide this wider innovation concept.

Companies that wish to adopt service-dominant logic in their innovation activities can start by aiming their innovation efforts at the development of new systemic value co-creation practices. New innovation capabilities are needed for creating a deep insight of multiplestakeholder situations and an understanding of institutional forces. In addition to these new capabilities, practices of entrepreneurial search and co-development need to be developed. Systemic change can be facilitated by identifying critical gaps of the system and developing technologies, products, and services to fill them. They are important enablers of human-to-human value co-creation and as such remain an integral part of innovation outcomes in service-dominant logic.

\section{Acknowledgements}

The author wishes to thank the case company's representatives, her dissertation advisor Professor Marja Toivonen, and her project companions Iiro Salkari and Tiina Apilo for participating in value co-creation. This article was written as part of the Finnish Metals and Engineering Competence Cluster's (FIMECC) Future Industrial Services program. It is based on a paper presented at the ISPIM 2013 Symposium.

\section{About the Author}

Heidi M. E. Korhonen is a professional in business development and research with a long experience of industrial and technology companies. She works as a Senior Scientist at VTT Technical Research Centre of Finland, in VTT's research area of business ecosystems, value chains, and foresight. She is also finishing her Doctoral Dissertation on industrial service innovation at Aalto University in Helsinki, Finland. Her research focus is on business development, innovation management, and value co-creation. Her current research interests cover service business, business ecosystems, business models, sustainability, open innovation, co-development, systems thinking, and customer and stakeholder orientation. She has published her research widely in international peer-reviewed journals, books, and conferences.

\section{References}

Akaka, M. A., \& Vargo, S. L. 2013. Technology as an Operant Resource in Service (Eco)systems. Information Systems and e-Business Management, 1-18.

http://dx.doi.org/10.1007/s10257-013-0220-5

Akaka, M. A., Vargo, S. L., \& Lusch, R. F. 2013. The Complexity of Context: A Service Ecosystems Approach for International Marketing. Journal of International Marketing, 21(4): 1-20. http://dx.doi.org/10.1509/jim.13.0032

Arthur, W. B. 2009. The Nature of Technology: What It Is and How It Evolves. New York: Free Press. 


\section{Widening the Perspective on Industrial Innovation: A Service-Dominant-Logic Approach}

\section{Heidi M. E. Korhonen}

Baines, T. S., Lightfoot, H. W., Benedettini, O., \& Kay, J. M. 2009. The Servitization of Manufacturing: A Review of Literature and Reflection on Future Challenges. Journal of Manufacturing Technology Management, 20(5): 547-567. http://dx.doi.org/10.1108/17410380910960984

Carlborg, P., Kindström, D., \& Kowalkowski, C. 2014. The Evolution of Service Innovation Research: A Critical Review and Synthesis. The Service Industries Journal, 34(5): 373-398. http://dx.doi.org/10.1080/02642069.2013.780044

Coombs, R., \& Miles, I. 2000. Innovation, Measurement and Services: The New Problematique. In J. S. Metcalfe \& I. Miles (Eds.), Innovation Systems in the Service Economy: 85-103. Boston, MA: Springer US.

Drucker, P. F. 1964. Managing for Results. New York, NY: HarperBusiness.

Edvardsson, B., \& Tronvoll, B. 2013. A New Conceptualization of Service Innovation Grounded in S-D Logic and Service Systems. International Journal of Quality and Service Sciences, 5(1): 19-31. http://dx.doi.org/10.1108/17566691311316220

Evanschitzky, H., Wangenheim, F. V., \& Woisetschläger, D. M. 2011. Service \& Solution Innovation: Overview and Research Agenda. Industrial Marketing Management, 40(5): 657-660. http://dx.doi.org/10.1016/j.indmarman.2011.06.004

Gallouj, F. 2002. Innovation in the Service Economy: The New Wealth of Nations. Cheltenham, UK: Edward Elgar Pub.

Giddens, A. 1984. The Constitution of Society: Outline of the Theory of Structuration. Cambridge: Polity.

Grönroos, C., \& Helle, P. 2010. Adopting a Service Logic in Manufacturing: Conceptual Foundation and Metrics for Mutual Value Creation. Journal of Service Management, 21(5): 564-590. http://dx.doi.org/10.1108/09564231011079057

Holbrook, M. 1999. Consumer Value: A Framework for Analysis and Research. London: Routledge.

Lundvall, B.-Å. 2007. Innovation System Research - Where It Came From and Where It Might Go. Globelics Working Paper Series, No. 2007-01.

Maglio, P. P., \& Spohrer, J. 2013. A Service Science Perspective on Business Model Innovation. Industrial Marketing Management, 42(5): 665-670.

http://dx.doi.org/10.1016/j.indmarman.2013.05.007

Mathieu, V. 2001. Product Services: From a Service Supporting the Product to a Service Supporting the Client. Journal of Business \& Industrial Marketing, 16(1): 39-61.

http://dx.doi.org/10.1108/08858620110364873

Michel, S., Brown, S. W., \& Gallan, A. S. 2008. Service-Logic Innovations: How to Innovate Customers, Not Products. California Management Review, 50(3): 49-65. http://dx.doi.org/10.2307/41166445

Neely, A. 2008. Exploring the Financial Consequences of the Servitization of Manufacturing. Operations Management Research, 1(2): 103-118.

http://dx.doi.org/10.1007/s12063-009-0015-5
Oliva, R., \& Kallenberg, R. 2003. Managing the Transition from Products to Services. International Journal of Service Industry Management, 14(2): 160-172. http://dx.doi.org/10.1108/09564230310474138

Ramaswamy, V. 2009. Leading the Transformation to Co-Creation of Value. Strategy \& Leadership, 37(2): 32-37. http://dx.doi.org/10.1108/10878570910941208

Ramaswamy, V. 2011. It's about Human Experiences... and Beyond, to Co-Creation. Industrial Marketing Management, 40(2): 195-196. http://dx.doi.org/10.1016/j.indmarman.2010.06.030

Read, S., Dew, N., Sarasvathy, S. D., Song, M., \& Wiltbank, R. 2009. Marketing Under Uncertainty: The Logic of an Effectual Approach. Journal of Marketing, 73(3): 1-18.

http://dx.doi.org/10.1509/jmkg.73.3.1

Rogers, E. M. 2003. Diffusion of Innovations (5th edition). New York: Free Press.

Schatzki. 2005. Introduction. In K. K. Cetina, T. R. Schatzki, \& E. von Savigny (Eds.), The Practice Turn in Contemporary Theory: 50-63. London: Routledge.

Schumpeter, J. A. 1934. The Theory of Economic Development: An Inquiry into Profits, Capital, Credit, Interest, and the Business Cycle. New Brunswick, N.J: Transaction Publishers.

Tidd, J., Bessant, J., \& Pavitt, K. 2001. Managing Innovation: Integrating Technological, Market, and Organizational Change, (Second Edition). Chichester, England: Wiley.

Vandermerwe, S., \& Rada, J. 1988. Servitization of Business: Adding Value by Adding Services. European Management Journal, 6(4): 314-324.

http://dx.doi.org/10.1016/0263-2373(88)90033-3

Vargo, S. L., \& Lusch, R. F. 2004. Evolving to a New Dominant Logic for Marketing. Journal of Marketing, 68(1): 1-17. http://dx.doi.org/10.1509/jmkg.68.1.1.24036

Vargo, S. L., \& Lusch, R. F. 2006. Service-Dominant Logic: What It Is, What It Is Not, What It Might Be. In R. F. Lusch \& S. L. Vargo (Eds.), The Service-Dominant Logic of Marketing: Dialog, Debate, and Directions: 43-56. New York: M.E. Sharpe.

Vargo, S. L., \& Lusch, R. F. 2008. Service-Dominant Logic: Continuing the Evolution. Journal of the Academy of Marketing Science, 36(1): $1-10$. http://dx.doi.org/10.1007/s11747-007-0069-6

Vargo, S. L., \& Lusch, R. F. 2011. It's All B2B...and Beyond: Toward a Systems Perspective of the Market. Industrial Marketing Management, 40(2): 181-187. http://dx.doi.org/10.1016/j.indmarman.2010.06.026

Yin, R. K. 1994. Case Study Research: Design and Methods (Second Edition). Thousand Oaks: SAGE Publications, Inc. 